\title{
Poverty, Dickens's Oliver Twist, and J. R. McCulloch
}

\author{
Dr. Öğr. Gör. Ayşe Çelikkol \\ Bilkent Üniversitesi, İnsani Bilimler ve Edebiyat Fakültesi \\ Ingiliz Dili ve Edebiyatı \\ celikkol@bilkent.edu.tr
}

\begin{abstract}
As the precursor to the science of economics, political economy concerned some topics that also preoccupied novelists, such as poverty and wealth. Literary criticism in the late twentieth and early twenty-first centuries has been charting the ways in which the discourses of literature and political economy intersect, despite the Romantic disavowal of their commonalities. Aiming to contribute to this ongoing scholarly effort, this essay pinpoints an unexpected affinity between Charles Dickens's Oliver Twist, a novel which addresses the plight of the poor under the New Poor Law of 1834, and the political economist J. R. McCulloch's writing on that piece of legislation. Both mistrust theoretical knowledge and privilege the particular as the basis on which one must make decisions. This affinity is unexpected because Oliver Twist repudiates political economy. Recognizing McCulloch's and Dickens's common epistemology alerts us to the ways in which the preference for the particular over the systemic shapes Oliver Twist. The common ground between Oliver Twist and McCulloch's writing on the New Poor Law attests to the interconnectedness of literature and political economy.
\end{abstract}

Keywords: Oliver Twist, Charles Dickens, New Poor Law, political economy, J. R. McCulloch.

\section{Fakirlik, Dickens'ın Oliver Twist Adlı Eseri ve J. R. McCulloch}

\section{Öz}

İktisat biliminin öncüsü olan politik ekonomi, romancıları da meşgul eden fakirlik ve varlık gibi kavramlarla ilgilendi. Yirminci yüzyılın sonunda ve yirmibirinci yüzyılın başında, edebiyat eleştiri, edebiyat ve politik ekonomi söylemlerinin, Romantik akımın aralarındaki bağlantıyı reddetmesine rağmen nasıl kesiştiğini gösterir. Bu süregelen akademik çabaya katkıda bulunmayı amaçlayan bu makale, Charles Dickens'ın 1834 Yeni Fakir Kanunu altında fakirlerin çektiği zorlukları ele alan Oliver Twist adlı eseri ile, politik ekonomi yazarı J R McCulloch'nun aynı kanun hakkındaki yazıları arasında şaşırtıcı bir benzeşme yakalar. Her ikisi de teorik bilgiye güvenmezler ve bir karar verirken dikkate alınması gereken kriter olarak tekillikleri ön plana çıkarırlar. Bu benzeşme şaşırtıcıdır, çünkü Oliver Twist politik ekonomiyi benimsemez. McCulloch'nın ve Dickens'in ortak bilgi kuramını farketmek, tekilliklerin sistemsel olana üstünlügünün Oliver Twist'i nasıl şekillendirdiğini görmemizi sağlar. Oliver Twist ve McCulloch'nun Yeni Fakir Kanunu 
üzerine yazılarının ortak noktaları, edebiyat ve politik ekonomi söylemlerinin birbirine ne kadar bağlantılı olduğuna işaret eder.

Anahtar Kelimeler: Oliver Twist, Charles Dickens, Yeni Fakir Kanunu, politik ekonomi, J. R. McCulloch. 


\section{INTRODUCTION}

Published serially from 1837 to 1839, Charles Dickens's Oliver Twist engages one of the most controversial economic and political topics of its time, the passing of the New Poor Law, which transformed the state's approach to poor relief-the provision of assistance to the poor-in Britain. The new legislation was based on "less eligibility, a principle which implied that "the condition of a pauper on relief should be less comfortable than that of the poorest self-supporting worker" (Schlicke, 1975, p. 150). The New Poor Law imposed the notorious "workhouse test," which meant that the workhouse, the institution where the poor had to labor to receive aid, was "deliberately made harsh and mean," and constituted the "only form of relief for the able-bodied" (Schlicke, 1975, p. 150). Oliver Twist takes political economists to task for their support of the New Poor Law, and Dickens repudiates their branch of inquiry, which claimed to study the production, distribution, and consumption of wealth from a scientific perspective.

Dickens appears to be critical of contemporary political economy's embrace of the New Poor Law; however, as this paper maintains, his criticism ignores some resistance to this legislation among political economists. One prominent political economist, John Ramsay McCulloch, was critical of the New Poor Law, like Dickens. Further, both McCulloch and Dickens related the problems pertaining to that law to the domination of abstract theories over concrete particulars. In other words, for both McCulloch and Dickens, economic crisis followed from an epistemological failure: excessive theorization, virtually ubiquitous in economic thinking, made it difficult to favor humane laws or implement effective poor relief. The goal of this article is to show that Dickens's approach to the New Poor Law was aligned with the political economist McCulloch's ideas on the issue, even as Dickens sought to situate his work as an alternative to political economy. Acknowledging this similarity reveals that Oliver Twist privileges the individual over the systemic even as it criticizes selfserving individualism.

\section{On the Intersections of Literature and Political Economy}

Today literature and economics are separate discourses and may even sometimes appear oppositional in their goals and methodologies. Starting in the late eighteenth century, the Romantics had posited an antithesis between the literary imagination and the sphere of commerce, as if the latter would poison the former (Woodmansee and Osteen, 1999, p. 6). This legacy continued to exert an influence after the end of the Romantic period, producing a sense of opposition between economic thought and activity on the one hand and literary and artistic pursuits on the other. However, especially in the late twentieth and the early twentyfirst centuries, critics such as Mary Poovey and Catherine Gallagher have sought to understand how literature and economic thought mutually informed and influenced each other, rather than constituting separate spheres. Poovey, Gallagher, and many others from Kathleen Blake to Eleanor Courtemanche, have explored the confluences and divergences of literature and economic thought.

Poovey's Genres of the Credit Economy charts the historical process through which two genres-literature and "writing about economics and finance" (2008, p. 7)-historically became distinct even though they had common origins. Poovey writes, "what economic writing and Literary writing share, both historically and theoretically, is an engagement with the problematic of representation" (2008, p. 5). The question of whether literature presents content with real-life referents has intrigued many a reader, and a similar question historically 
haunted those who dealt with monetary instruments and other documents of economic value. Consider those who lost money in the South Sea Bubble in 1720. When the stocks collapsed, "English men and women were left wringing their collective hands over the fictions inherent in the modern credit economy" (Poovey, 2008, p. 6). Poovey writes, "the different strategies by which each set of genres managed the problematic of representation helped give the modern disciplines their distinctive forms" $(2008$, p. 6). In other words, while both literature and economic writing were preoccupied with representation, the exploration of it in each genre took different forms. The practitioners of these genres often denied their common preoccupations: "by the 1740s, this denial began to take the form of generic differences (novels as opposed to financial commentary ...), which were increasingly equated with . . . the distinction between fact and fiction" (2008, p. 7). Through the differentiation of these genres, it seemed that one corresponded to facts and the other to fiction, even though, as in the case of the South Sea Bubble, fiction was at work in the maintenance and even growth of the economic system.

According to Poovey, the understanding that each of these genres-literature and economic writing-mediated different kinds of value came to define their identities in the eighteenth and nineteenth centuries. Poovey's majestic book outlines this process of differentiation while remaining attentive to the common premises of the genres:

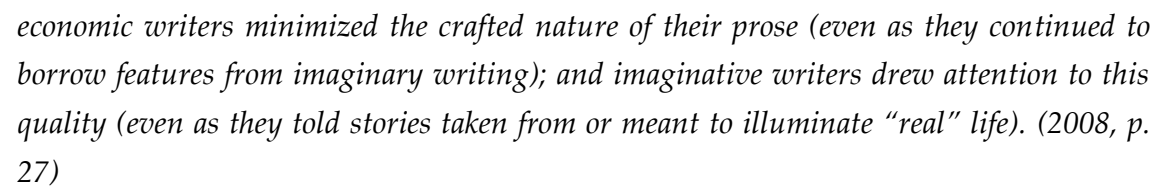

Literary authors distinguished their efforts by claiming their writing was imaginary. Yet these genres undertook a single function, that of "mediating value" (Poovey, 2008, passim). Literature claimed to embody a sort of value that appeared to transcend market transactions. In the case of economic writing, the value that the authors investigated was dependent on the market. Poovey summarizes: "All these genres initially performed a single function-they helped Britons understand and learn how to negotiate the market model of value" (2008, p. 25). As literary and economic writing became differentiated, they became "incommensurabl[e]" (2008, p. 28). At that stage, comparing them for their similarities seemed far-fetched despite their common origins. Poovey's work sheds light on the operation of genre-its operation, logic, function, limits-as it discusses the relation between literature and economic writing.

Catherine Gallagher's Life, Death, and Sensation in Political Economy and the Victorian Novel similarly attends to what literature and economic writing have in common, while exploring their historical divergence. Poovey focuses on many kinds of economic writing such as bank notes and economic treatises, but Gallagher is especially interested in political economy, which claimed to be a branch of science charting the production, distribution, and consumption of wealth. As Gallagher notes, criticism in the field of nineteenth-century British studies has "demonstrated that political economists and their literary antagonists had a great deal in common, which they were frequently unwilling to recognize" (2006, p. 2). Even though the two discourses made similar inquiries, their practitioners claimed to have little in common. Gallagher writes, "political economists and their Romantic and early Victorian critics jointly relocated the idea of ultimate value from a realm of ultimate spiritual meaning to organic 'Life' itself and made human sensations-especially pleasure and pain-the sources and signs of that value" 
(2006, p. 3). Both literature and political economy, as secular discourses, took pleasure and pain to be the yardsticks by which to allocate value even though the practitioners of literature at times claimed their approach to value was antithetical to those of the political economists.

According to Gallagher, in political economy, the interest in life and sensations took two major forms, "bioeconomics" and "somaeconomics," inspired by the ideas of Thomas Malthus and Jeremy Bentham, respectively (2006, p. 3). In bioeconomics, the focus is on "interconnections among populations, the food supply, modes of production and exchange, and their impact on life forms generally" (2006, p. 3). The sustenance of life, dependent on the supply of food, is at the cornerstone of such considerations. In somaeconomics, the organic continues to play a major role, though the emphasis is not on life as such but feelings. Gallagher describes somaeconomics as "the theorization of economic behavior in terms of the emotional and sensual feelings that are both causes and consequences of economic exertions" (2006, p. 3). Pain and pleasure explained the human subject's self-interested behavior, according to some versions of political economy.

Gallagher's argument is that both bioeconomics and somaeconomics are relevant to literature of the nineteenth century. For example, both "found their way into the plots of Charles Dickens," even though the novelist was hostile to political economy (2006, p. 4). George Eliot "accommodated" these two approaches as well, though her "appropriations" of these ideas were not "uncritical" (2006, p. 5). Analyzing four novels in her book, Gallagher maintains that somaeconomics and bioeconomics appear in these novels. Specifically, they "have stylistic, structural, and thematic manifestations; they shape the plots and modes of characterization" (2006, p. 5). The analysis of these novels benefits immensely from taking political economy into account. For Gallagher, such an interdisciplinary approach does not just lead to a better understanding of the novels' themes. It also illuminates the form of the novel. The form of fiction is in part constituted by reference to the common ground between literature and political economy.

Inspired by the works of Mary Poovey, Catherine Gallagher, and others who shed light on the confluence and divergence of literature and political economy, this article explores the tension between Dickens's overt repudiation of political economy in Oliver Twist and what his thinking has in common with the political economist J. R. McCulloch. To recognize this novel's resonance with the ideas of J. R. McCulloch, it is first necessary to recognize that political economy is not monolithic and that its practitioners sometimes disagreed with one another. J. R. McCulloch disagreed with those political economists who wished to abandon the old poor law.

To consider political economy in this context is to foreground epistemological questions that shape the form of the novel. This article argues that the novel's closure is informed by the epistemology that Dickens and McCulloch held in common: the privileging of the particular and the critical attitude toward over-theorization. In this manner, the article seeks to add to existing criticism that discovers unlikely affinities between Dickens and economic thinkers. While it is customary to read Oliver Twist as a critique of the Benthamite values that the Poor Laws embody, Peter M. Stokes has shown that Dickens and Jeremy Bentham were both self-critical of their own stances (2001). Shifting the focus to McCulloch, this article brings into focus Oliver Twist's affinity with the ideas of this political economist.

SEFAD, 2021; (45): 35-48 


\section{The Criticism of Political Economy in Oliver Twist}

Oliver Twist's plot overtly addresses poverty and other issues pertaining to the New Poor Law, such as the workhouse. A brief plot summary is in order, as the intricate storyline takes quite a few turns. Oliver the orphan is raised in a workhouse, the kind of institution where the poor historically had to live after the passing of the New Poor Law. Living with Mrs. Mann, an employee of the workhouse, Oliver is deprived of decent care. Then, while still a child, he confronts toilsome work in the workhouse. This is where Oliver, hungry after a meager meal, tells the parish beadle that he wants some more food. After this turning point, the authorities seek to give Oliver out as an apprentice. An undertaker takes him as his apprentice, but his wife mistreats the boy, and so does a fellow apprentice. After the events escalate, Oliver decides to run away to London.

On his way to London, Oliver meets a gang of boys whom he fails to recognize as pickpockets. Fagin, who organizes and benefits from the boys' activities, offers Oliver a place to stay, and soon enough attempts to train him as a pickpocket. Two of the boys steal a gentleman's handkerchief and set up Oliver for the crime. Despite the set-up, the gentleman, Mr. Brownlow, believes Oliver to be innocent and takes him home to take care of him. However, Fagin plots to have Oliver brought back and succeeds, through no fault of the boy. However, Mr. Brownlow does not know that the boy was taken against his will. Fagin arranges for Oliver to rob a house, but Oliver seeks refuge with the people whose house he was supposed to help rob.

A man named Monks has been influencing Fagin to turn Oliver into a criminal. Nancy, a young woman Oliver had met at Fagin's, overhears the full story that motivates this action: there is a locket and ring revealing the identity of Oliver's parents, which Monks secures and disposes of. Nancy secretly meets Mr. Brownlow to tell him what she knows of Oliver's story, but is subsequently tragically killed by her boyfriend Sikes, who thinks she has betrayed him. Sikes flees after killing her, but ends up hanging himself by accident as he flees those enraged by Nancy's murder. Once the novel reveals that Monks is actually Oliver's half-brother, it ties up the loose ends, charting out the trajectories of its major characters. Especially significant is the story of Rose Maylie. When Oliver is forced to help rob a house and takes shelter in the house they were going to rob, he ends up staying with Rose Maylie, who later turns out to be his aunt.

Oliver Twist is critical of political economy, and its repudiation of self-reliance is where this critique surfaces most incisively. In the novel, Fagin and his gang of pickpockets adopt the language of political economists who assumed that individuals were free to make choices that would lead to financial success. When Oliver is reluctant to steal, the Artful Dodger asks him, "Don't you take any pride out of yourself? Would you go and be dependent on your friends?" (Dickens, 1988, p. 182). Being a thief from this perspective appears to be a kind of self-reliance, a quality that many Victorians cherished. The comment, of course, overlooks thieves' dependence on their victims. Thieves may not be dependent on their friends, but this is an illusory independence. Through the Artful Dodger's comment, Dickens mocks the political economy's applause for self-reliance. As Dickens highlights, situations in which we assume someone is independent may involve dependencies we are overlooking. This insight is what Oliver Twist reaches toward through the irony of the thief's comment. In addition to critiquing the political economists' rhetoric for its blindness to social dependence, the Artful Dodger's formulation subtly raises a haunting possibility: what if legitimate gains rely on 
immoral expropriation just like the Dodger's methods? In other words, what if all selfreliance relies on acts of expropriation, the assumption of unjust gain? This is the most radical of the suggestions that the boy's comment provokes, and one that the novel does not pursue. Through the characterization of Mr. Brownlow, Oliver Twist represents wealth whose manner of acquisition it does not question. It thus abandons the radical possibility implicit in the boy's comment.

Dickens continues to criminalize the rhetoric of political economists when he has Fagin elaborate his philosophy of "number one." "Everyone's his own friend, my dear" says Fagin with a grin (Dickens, 1988, p. 386). Through this comment, Dickens attacks the maxim held by political economy since Adam Smith's Wealth of Nations - that everyone naturally serves his or her own self-interest first. According to Smith's account, there is nothing wrong with the pursuit of self-interest, because society as a whole benefits from it. In Dickens's rendition, however, the cornerstone of Smith's thought has become a criminal maxim. Echoing Smith's principle of the invisible hand, Fagin even outlines how selfishness is the guarantor of the wellbeing of others ("you can't consider yourself as number one without considering me too as the same" [1998, p. 387]). This abstruse formulation may justify why it is fine to consider yourself number one, but of course, coming from Fagin, it is suspect and not likely to sound persuasive. Oliver Twist in this sense portrays the ideology of political economy to be bankrupt. It presents political economy as a discourse to which criminals resort in order to justify their actions.

\section{The Poor Laws and the Political Economists}

The political economists did indeed extol self-reliance, as many political ecoomists' advocacy of the abandonment of the Elizabethan Poor Law demonstrates. Some well-known political economists embraced the abandonment of this older Poor Law. Thomas Malthus and David Ricardo opposed the old Poor Law because they believed that individual or state aid was, in the long run, to the detriment of the laboring classes: the solution to the ills of poverty, wrote Ricardo, was "gradually contracting the sphere of the poor laws; ... impressing on the poor the value of independence, ... teaching them that they must look not to systematic or casual charity, but to their own exertions for support" (Ricardo, 1996, p. 74). Ricardo supposes that the poor are poor because they do not value independence. It is as if he assumed that they were poor by choice. Had they understood the importance of self-reliance, they would not need to seek private charity or state support. This line of reasoning informed Ricardo's dislike for the old Poor Law.

As the historian of economic thought Mark Blaug writes, "the kind of arguments which are used to condemn the Old Poor Law per se would equally condemn most modern welfare legislation" (Blaug, 1963, p. 152). Blaug's comment helps us understand where Ricardo would stand if positioned in our contemporary world. The welfare state, which endeavors to take care of its citizens, was not around at the time Ricardo was writing; it emerged in its modern form in the middle of the twentieth century in Britain. Usually associated with social democracy, the welfare state protects its citizens through such means as public pensions. The modern welfare state and the New Poor Law are products of antithetical political drives, one for and the other against the state's protection of its citizens. A political economist like Ricardo who supported the New Poor Law stood for the political position that later became the antithesis of the welfare state.

SEFAD, 2021; (45): 35-48 
The Old Poor Law had been relatively beneficial to the poor (Blaug, 1963, p. 152). "The Old Poor Law tried to maintain the real income of workers by tying wages to the cost of living; it provided unemployment compensation together with a scheme to promote private employment," writes Blaug (1963, p. 152). In the 1820s, Thomas Malthus, David Ricardo, and many other political economists had sought to repeal the existing system of poor relief, under which earnings below a standard level were supplemented by the parish. Malthus's and Ricardo's notorious effort to get rid of the old system of poor relief was based on the premise that public provision for the poor in the long run resulted in lower wages for the working class.

The New Poor Law of 1834 was indeed a compromise: the protections guaranteed by the old Poor Law partly continued, although it implemented such invidious measures as the workhouse test that eliminated outdoor relief, the assitance to the poor outside the workhouse. Of the two major engineers of the new law, neither Edwin Chadwick, a disciple of Bentham, nor Nassau Senior, a political economist, was for the complete abolition of the Elizabethan Poor Law. They preferred an amendment to it. The system they devised reaffirmed the need for public provision, but it obeyed the logic of laissez-faire insofar as it aimed to re-direct labor to the market. The New Poor Law stipulated that "the condition of the able-bodied pauper be 'less eligible'-desirable, agreeable, favorable - than that of the 'lowest class' of independent laborer" (Himmelfarb, 1984, p. 163). This meant that workhouse conditions had to be kept at a level lower than what the working-class experienced outside it. To Dickens and many others, this level was not acceptable, and they lamented that the poor under the New Poor Law were miserable in the workhouses. The goal of the New Poor Law was to have the poor opt to work: "What was new about [the Commision's proposal] was its function in distinguishing pauper and poor" (Himmelfarb, 1984, p. 164). In contrast to the condition of lesseligibility, the older system had maintained a "single standard of subsistence" based on the price of bread, without stipulating how its level should compare to the wages of the independent laborer (Himmelfarb, 1984, p. 164). It was for this reason that many considered the old system more humane.

\section{Oliver Twist and the New Poor Law}

In a letter of 1842, Dickens declared, "I do differ from [Mr. Chadwick] to the death on his crack topic-the New-Poor Law" (1965, p. 480). Oliver Twist testifies to this difference (Schlicke, 1975; Fielding, 1987). The destructive workhouse where the little boy arrives after leaving Mrs. Mann's baby farm operates according to the New Poor Law's principle of lesseligibility, which amounts to starvation:

Poor Oliver! He little thought, as he lay sleeping in happy unconsciousness of all around him, that the board had that very day arrived at a decision which would exercise the most material influence over all his fortunes. But they had. And this was it:

The members of this board were very sage, deep, philosophical men, and when they came to turn their attention to the workhouse, they found out at once, what ordinary folks would never have discovered-the poor people liked it! It was a regular place of public entertainment for the poorer classes; a tavern where there was nothing to pay; a public breakfast, dinner, tea, and supper all the year around; a brick-and-mortar Elysium, where it was all play and no work. . So, they established the rule, that all poor people should have the alternative (for they would compel nobody, not they), of being starved by a gradual process in the house, or by a quick one out of it [.] (Dickens, 1988, p. 54-55) 
The narrator calls the old workhouse a "place of public entertainment" with full irony, to highlight the misconceptions of those who supported the New Poor Law. It is only the board who thinks of the old workhouse that way, not the poor themselves. Like the Royal Commission that investigated the Old Poor Law and devised the new one, the fictional board wants the conditions within the workhouse to deteriorate.

In this passage, the narrator criticizes the new system without idealizing the old. What makes the new system problematic is its assumption that the old offered too much. The most memorable attack on laissez-faire occurs as the narrator pinpoints a contradiction. Laissez-faire is a system against state intervention, but here state intervention is necessary to uphold its principles. In mocking the board for "not compel[ling] anyone," the narrator astutely captures the paradox of the New Poor Law. The presumed function of the new system was to channel "'free' labour onto a competitive market," which paradoxically could be achieved only by the centralization of the workhouse system and the establishment of a central board to "enforce regulations for the management of the workhouses" (Driver, 1993, p. 19; Himmelfarb, 1984, p. 165). As the narrator's ironic comment aptly captures, laissez-faire contradicts its own agenda if strong state intervention is necessary to instate it. This passage shows the supporters of the New Poor Law contradicting themselves.

Critical as Dickens himself may have been of the discourse of self-reliance, the vision he offers in the novel seems to favor private charity based on face-to-face contact in the style of Mr. Brownlow or the Maylies, rather than public provision for the poor. ${ }^{1}$ So if Oliver Twist opposes the New Poor Law, this does not indicate an enthusiasm for transforming the underlying economic system. In Dickens's vision, it is charitable deeds that will spontaneously provide for the poor.

\section{J. R. McCulloch's Stance on the New Poor Law}

Not all political economists favored the New Poor Law. Malthus and Ricardo's desire to do away with poor relief, which received criticism from Dickens, was also disparaged by John Ramsay McCulloch. Influenced by the Morning Chronicle editor John Black, McCulloch notably "favored a return to the pre-1795 'Elizabethan' Poor Law, with its emphasis on local administration of relief and its guarantee of employment and subsistence to the able-bodied poor who could not support themselves" (Gilbert, 1985, p. 507). McCulloch had initially agreed with Ricardo and Malthus, but he appears to have changed his mind around 1826 ( $\mathrm{O}^{\prime} \mathrm{Brien}, 2003$ ). In 1828, at the height of the Poor Law debate, McCulloch maintained that arguments put forth by apologists for the existing system were "well-founded in fact" (McCulloch, 1828, p. 304). In the old system, the "aversion of the poor" to the workhouse system was "great" - that is, they did not prefer to stay idle and simply rely on aid (McCulloch, 1828, p. 307). That is, no extra measures were necessary to render the workhouse unappealing. Unlike Malthus and Ricardo, McCulloch found that the system of "compulsory provision" worked well, in part because landlords "oppose[d] themselves to the increase of the labouring population" by being "exceedingly cautious about admitting new settlers upon their estates or farms" (McCulloch, 1828, p. 309). McCulloch was for state intervention as far as poor relief was concerned: "is it not, plainly, the duty of a wise government to adopt measures for the prevention of so great an evil?" he asked, as he attended to the "want and wretchedness" of the lower classes (McCulloch, 1828, p.

${ }^{1}$ Lauren Goodlad points out that Dickens's social critique ("trenchant satire on middle-class respectability") coexists with his "idealization of middle-class character" (Goodlad, 2003, p. 61).

SEFAD, 2021; (45): 35-48 
313). Dickens's caricature of "philosophical men" in Oliver Twist overlooks McCulloch's support for the public provision for the poor.

\title{
Skepticism toward Theoretical Knowledge
}

The discourse of political economy was not monolithic with regard to the Poor Laws, and McCulloch had more in common with Dickens than he did with Malthus or Ricardo when it came to poor relief. What McCulloch's writing on the Poor Laws shares with Oliver Twist is an epistemology - both are skeptical of theoretical knowledge. McCulloch opens his 1828 Edinburgh Review article with an emphatic declaration: "We shall have very little to do with theory in this article" (McCulloch, 1828, p. 303). As political economists sought to derive abstract laws from "observed particulars" (Poovey, 1998, p. xv), McCulloch's opening stance announces a departure from the standard method of the discipline. McCulloch finds that individual observations contradict some universal laws that political economony formulates:

\begin{abstract}
it is almost universally admitted, in their practical operation, that they [the Old Poor
Laws] tend to render the poor idle and improvident; that they teach them to depend on parish assistance, instead of trusting their own exertions. . . It seems impossible to doubt the correctness of these conclusions, and yet it is no easy matter to reconcile them to what has actually taken place. (McCulloch 1828, p. 303)
\end{abstract}

McCulloch singles out and critiques multiple layers of abstraction here. Advocates of the abolition of the Old Poor Law start with one generalization (Malthus's theory of population) to arrive at another (the Poor Laws, by providing a disincentive to work, do a disservice to the poor). In the rest of the article, McCulloch collects particulars contradicting the assumption that public provision breeds idleness. There is no attempt to arrive at an alternative universal law; casting the theoretical aside, he valorizes the observed particulars for their own sake. He admits the mismatch between the abstractions of political economy and the facts that he lists without attempting to account for it: "Such, in a few words, is the substance of the statements that are occasionally put forth by the apologists of the Poor Laws. And, however inexplicable they may appear, it is impossible to deny that they are well founded in fact" (McCulloch, 1828, p. 304). He obfuscates the validity of the universal law, resorting instead to observed particulars in the form of numerical facts organized in tables. Such tables are not rare in political economic treatises. What is notable in this instance is that they have become detached from abstract principles.

Political economy as a whole defended and even idolized the individual at the level of ideology. Methodologically, however, it was confident that singularities could be translated into abstractions. In suggesting the difficulty of moving from the individual to the theoretical, McCulloch here expresses some discomfort with the very methodology of political economy when it comes to the issue of poor relief. In this specific instance, he questions the efficacy of theoretical thinking.

Oliver Twist is similarly critical of the theoretical. ${ }^{2}$ Knowledge derived from actual experience trumps over that provided by abstractions:

Everybody knows the story of another experimental philosopher, who had a great theory about a horse being able to live without eating, and who demonstrated it so well, that he got his own horse down to a straw a day, and would unquestionably have rendered him a

${ }^{2}$ For Goodlad, the novel singles out "impersonal rules" as the source of the problem (p. 69). 
very spirited and rampacious animal on nothing at all, if he had not died. (Dickens, 1998,

p. 48)

The mismatch between the theory and the observed particular proves fatal. Like McCulloch, Dickens attends to stubborn facts that contradict the theories that they are supposed to evince. Like theories, systems are suspect in Dickens's epistemology - they tend to overlook lived experience and obey abstract principles at the expense of the individual. The baby farm where Oliver is sent reaffirms the failure of the systemic: "Unfortunately for the experimental philosophy of the female to whose protecting care Oliver Twist was delivered over, a similar result usually attended the operation of her system" (Dickens, 1988, p. 48). Dickens pits the systemic against the particular, favoring the latter over the former. As James Buzard puts it, Dickens "mistrusted systems" (2017, p. 1237). The systemic in this instance is suspect because it is out of touch with face-to-face experience.

\section{The Preference for the Particular Over the Systemic}

In both McCulloch's writing on the Poor Laws and Dickens's Oliver Twist, concrete particulars appear to oppose two things: abstract theories and large systems. Both are targets of criticism insofar as they seem antithetical to concrete particulars. Oliver Twist shows a preference for the particular over the theoretical or the systemic, despite its criticism of the pursuit of individual self-interest.

The use of individual characters who shoulder the blame for social ills or deserve our applause for making the world a better place evinces this tendency. For example, the figure responsible for most of the children's suffering in much of the novel is Fagin, a Jewish man. In addition to blaming the overall system of failed poor relief for social problems, Dickens singles out a racialized subject for criminalizing the children. The individual looms large in this account of social failure.

Charity, the solution for social ills in this novel, similarly presents an antithesis to systemic poor relief. If only the world were for full of people such as Mr. Brownlow or the Maylies, then there would be less suffering: the novel implies this perspective, and in doing so it presents individual goodwill as a solution to the problems it depicts. The happy ending cannot herald a system in place more effective than the New Poor Law, so Mr. Brownlow must adopt Oliver. Of course, claiming to write a "history," the narrator could not have made up a hypothetical, imaginary Poor Law that would replace the one that Dickens critiques. It does not make sense to blame Dickens for failing to invent the welfare state. However, the narrator goes to great lengths at the end to suggest that goodwill like Mr. Brownlow's is the only force that can battle the vicissitudes of life: "[Mr. Brownlow] gratified the only remaining wish of Oliver's warm and earnest heart, and thus linked together a little society, whose condition approached as nearly to one perfect happiness as can ever be known in this changing world" (Dickens, 1998, p. 357). Their society is doomed to be "little" precisely because it is based on individual goodwill rather than systemic change. It is, nonetheless, a "society," and in this word we see a criticism of the atomic individualism that political economy hypothesized. As Lauren Goodlad puts it, for this novel "the crudest competitive individualism is the debased legacy of a society bent on creating man in the image of self-interested homo economicus" (2003, p. 68). The subjectivity shaped by the pursuit of economic self-interest gives way to charityoriented benevolence. The novel no doubt attacks what Goodlad calls competitive individualism even as it embraces expresses discomfort with the abstract and the systemic. Despite the criticism of competitive individualism, the novel privileges the individual 
subject as the unit of focus, the node where the threads of the story intersect. To be sure, the individual subject has limited agency in this novel. As Aleksandar Stević argues, the oscillation between self-fashioning and external determination marks the Dickensian bildungsroman (2014, p. 63-94). Individuals achieve visibility over the systemic, but they are not fully in control of their lives.

In Rose Maylie, one of the characters who is infinitely charitable to Oliver and helps to rescue him, the gender dynamics of Dickens's preference for individual goodwill surfaces. Dickens is able to assign women an important social role in part because the individual charity he embraces is recognized as a feminine trait. Rose Maylie's role in reforming society is one and the same with her feminine charm:

I would show Rose Maylie in all the bloom and grace of early womanhood, shedding on
her secluded path in life, such soft and gentle light, as fell on all who trod it with her, and
shone into their hearts. . I would watch her in all her goodness and charity abroad, and
the smiling untiring discharge of domestic duties at home (Dickens, 1998, p. 359).

Her charitable acts go hand in hand with her performance of domesticity. In this manner, the solution that Dickens proposes is placed in service of the Victorian cult of domesticity, which, as a middle-class ideology, favors the individual over the systemic.

The novel opens by critiquing the system and closes by centering the focus on the individual, despite its overt attack on selfishness. The failure to pursue a solution to social ills at a holistic level results in the relative frailty of the ending as an aesthetic product. To convey a happy ending, the last chapter of the novel provides a list, because its unit of analysis is the individual. By the end, Dickens's ability to capture the systemic as he does at the beginning of the novel is limited. What ensues is a point-by-point procession exposing what happens to each character, with little narrative thread tying the whole together. The narrator boasts of "weav[ing] . . . the thread of these adventures," but whether the final chapter in closure indeed offers a woven fabric-or merely isolated pieces of thread-is open to question. Precisely because systems have been associated with harmful abstractions, the emphasis on the individual comes at the expense of networks or webs. Formally, the list surfaces as the aesthetic of the individual, and signals a refusal to combine particulars into a system.

Yet the aesthetic of individualized items is impoverished compared to the large system of meaning we recognize as the novel. Insofar as the novel relentlessly puts particular elements in dialogue, it constitutes a system. Even a small portion of it, as language, belongs with systemic meaning-making. At the same time, characteristically focused on characters, the nineteenth-century novel must dwell on the individual. The systemic and the individual coexist in the novel as a form, even though the list-form that dominates in closure in Oliver Twist privileges the particular.

\section{CONCLUSION}

In seeking to restore the significance of the particular, Dickens is self-congratulatory. The genre in which he is writing characteristically privileges the particular: it is by tracing "the Parish Boy's Progress," as indicated in the novel's subtitle, rather than by offering abstractions that Dickens contributes to the Poor Law debate. Yet, as McCulloch's writing shows, economic writing too could problematize theory as well, and the methods of this 
particular political economist approached that of the novelist when he chose to privilege specific observations over abstract laws in this instance.

Fictional narratives and economic inquiries began to be perceived as separate genres in the eighteenth and nineteenth centuries in Britain. By the time Dickens was writing his novels, literature and political economy were perceived as separate discourses, each with its own conventions. Dickens reaffirmed the division between political economy and literature through the figures of the incompetent and unsympathetic board members in Oliver Twist as well as his disparagement of the criminal gang's emphasis on self-interest. Yet political economists produced a more diverse array of thought than is commonly recognized and there was dissent to the New Poor Law even among the political economists. What McCulloch shares with Dickens as far as his writing on the New Poor Law is concerned is the valorization of the particular. In Oliver Twist, the desire to trace the trajectories of a set of individuals stands in productive tension with the novel's more overt critique of atomic individualism. Rather than treat political economy and literature as oppositional, we must allow for discord within each and explore how their practitioners held some ideas in common even after the two discourses had become differentiated.

The cultural and political work that the novel and the discourse of political economy undertook overlapped. As Oliver Twist and McCulloch's writing on the New Poor Law show, both posited the value of the individual as a unit of analysis while also asserting the limits of their autonomy. The tension between the individual and the systemic animated both discourses and especially informed debates on how the state should provide assistance to needy subjects. Because of this overlap between the two discourses, it remains a valuable exercise today to consider the history of economic thought in analyses of literature.

Article Information

Ethics Committee Approval: Informed Consent:

Financial Support:

Conflict of Interest:

Copyrights:
Exempt from the Ethics Committee Decision.

No participant

No financial support from any institution or project.

No conflict of interest.

No material subject to copyright is included. 


\section{BIBLIOGRAPHY}

Blake, K. (2009). Pleasures of Benthamism: Victorian literature, utility, political economy. London: Oxford University Press.

Blaug, M. (1963). The myth of the Old Poor Law and the making of the new. The Journal of Economic History 23(2), 151-84.

Buzard, J. (2014). Item of mortality: lives led and unled in Oliver Twist. ELH: English Literary History 81(4), 1225-51.

Courtemanche, E. (2011). The invisible hand and British fiction, 1818-1860. Basingstoke: Palgrave Macmillan.

Dickens, C. (1965). Letters. Ed. Madeline House et al. Oxford: Oxford University Press.

Dickens, C. (1988). Oliver Twist. New York: Penguin Books.

Driver, F. (1993). Power and pauperism: the workhouse system, 1834-1884. New York: Cambridge University Press.

Fielding, K. J. (1987). Benthamite Utilitarianism and Oliver Twist: a novel of ideas. Dickens Quarterly 4(2), 49-65.

Gallagher, C. (2006). The body economic: life, death, and sensation in political economy and the Victorian novel. Princeton: Princeton University Press.

Gilbert, G. (1985). The Morning Chronicle, Poor Laws, and political economy. History of Political Economy 17(2), 507-21.

Goodlad, L. M. E.. (2003). Victorian literature and the Victorian state: character and governance in liberal society. Baltimore: The Johns Hopkins University Press.

Himmelfarb, G. (1984). The idea of poverty: England in the early industrial age. New York: Knopf.

McCulloch, John Ramsey. (1828). Poor Laws. Edinburgh Review 47(94), 303-330.

O'Brien, D. P. (2003). J. R. McCulloch: a study in classical economics. New York: Routledge.

Poovey, M. (2008). A history of the modern fact: problems of knowledge in the sciences of wealth and society. Chicago: The University of Chicago Press.

Poovey, M. (2008). Genres of the credit economy: mediating value in eighteenth- and nineteenthcentury Britain. Chicago: The University of Chicago Press.

Schlicke, P. (1975). Bumble and the Poor Law satire of Oliver Twist. The Dickensian 71, 149-65.

Stević, A. (2014). Fatal extraction: Dickensian bildungsroman and the logic of dependency. Dickens Studies Annual: Essays on Victorian Fiction 45(1), 63-94.

Stokes, P. M. (2001). Bentham, Dickens, and the uses of the workhouse. SEL: Studies in English Literature 41(4), 711-27.

Woodmansee, M \& Osteen M (1999). Introduction. The New Economic Criticism: Studies at the Intersection of Literature and Economics, eds. Woodmansee and Osteen. London and New York: Routledge. 